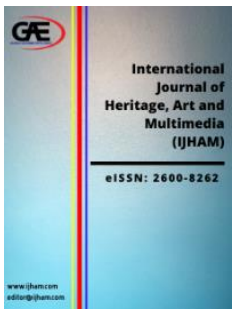

\author{
INTERNATIONAL JOURNAL OF \\ HERITAGE, ART AND MULTIMEDIA \\ (IJHAM) \\ www.ijham.com
}

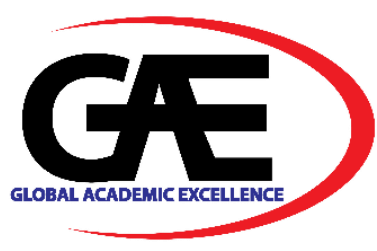

\title{
THE ART INCULTURATION OF THE CATHOLIC CHURCH OF THE SACRED HEART OF JESUS GANJURAN AND ITS IMPLICATIONS ON THE SPIRITUALITY OF THE PEOPLE
}

\author{
Tony Anwar Rosidy ${ }^{1 *}$, Sultan Prasasti ${ }^{2}$ \\ 1 Department of Performing Arts and Visual Arts Studies, Universitas Gadjah Mada, Indonesia \\ Email: tonyanwar2020@mail.ugm.ac.id \\ 2 Department of History, Universitas Negeri Yogyakarta, Indonesia \\ Email: sultanprasasti.2018@student.uny.ac.id \\ Corresponding Author
}

\section{Article Info:}

Article history:

Received date: 30.10 .2021

Revised date: 15.11. 2021

Accepted date: 27.11.2021

Published date: 01.12 .2021

\section{To cite this document:}

Rosidy. T. A., \& Prasasti, S. (2021). The Art Inculturation Of The Catholic Church Of The Sacred Heart Of Jesus Ganjuran And Its Implications On The Spirituality Of The People. International Journal of Heritage, Art and Multimedia, 4 (15), 33-45.

DOI: $10.35631 /$ IJHAM.415003.

This work is licensed under $\mathrm{CC}$ BY 4.0

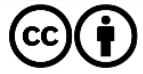

Abstract:

The connection between art and religion is found in several places. The Catholic Church of the Sacred Heart of Jesus Ganjuran, Yogyakarta is proof of the cohesion between art and religion in Indonesia. Inculturation is the process of adapting Catholic teachings with local culture, one of which is with art. This study aims to describe the cultural unquenching that occurred in the Catholic Church of the Sacred Heart of Jesus Ganjuran Yogyakarta and its implications on the spirituality of the people. This study uses descriptive qualitative methods with phenomenological approaches. The results showed that the inculturation that occurred resulted in a variety of art activities and art artifacts including Javanese liturgy, liturgical gamelan, Javanese architecture such as pendopo (Javanese pavilion), Javanese versions of Jesus and Mary statues and temples. The spirituality of the people is awakened with the concept of Java which is thick in its worship. Liturgical gamelan is one of the integral components in worship that makes a bond as man's sacred activity with God. The contemporary aspect can be seen from the gamelan classical rules that combine with the choir that forms a new aesthetic. It can touch the people in feeling the presence of God through local culture. The cohesiveness of the value of art and religion can stimulate people to experience the same religious and aesthetic experiences in worship.

Keywords:

Inculturation, Art, Religion 
Volume 4 Issue 15 (December 2021) PP. 33-45 DOI 10.35631/IJHAM.415003

\section{Introduction}

The discourse on art seems to have developed and touched other scientific disciplines. Art intersects with other disciplines and can reveal interesting phenomena as discourse and new knowledge. Western terminology is often used in studying a work of art because it is considered capable of presenting general correct theories. Local aesthetics is also able to be researched and narrated into a global discourse of art knowledge to complement art knowledge. The ability to elaborate on the findings associated with this critical review is what can generate new knowledge. The richness of local art that is still manifested in these metaphors needs to be studied and revealed to the public. The position of art science which is currently not too strong will become strong if it is able to intersect with other scientific disciplines. This study will discuss about music related to religion and culture. Religious and cultural studies are interesting and intertwined studies. Culture has many branches, one of which is art. Art is always interesting to talk about because it is related to the management of taste and aesthetics. The encounter of art and religion is also able to bring up new aesthetics that are interesting and have their own characteristics.

The connections that appear here are between components of art, religion, and culture, and they appear to have a significant relationship. The two disciplines of religion and art are inextricably linked. Religion and art are two basic things that cant be separated. Religion and art had an empirically tight link at beginning since they both possessed the same characteristics, namely ritual and emotional expression (Hadi, 2006:11). Sumardjo (2000:22) also said the same thing which means that artistic experience and religious experience are identical experiences, and it can also be said that the value of art is equivalent to religious value. Bahari (2017:68) also said that if art reaches its final goal, then it will participate together with religion and philosophy in interpreting and explaining the elements of divinity and most of the very deep and broad needs of humanity. The integration of art and religion can also be seen in one aspect of the Catholic church in Indonesia which is undergoing a process of inculturation. One of the Catholic churches that is known to be very strong in its inculturation process with Javanese culture is the Catholic Church of the Sacred Heart of Jesus Ganjuran, Yogyakarta.

The Catholic Church of the Sacred Heart of Jesus Ganjuran is a Catholic Church under the auspices of the Archdiocese of Semarang. This church located in Ganjuran, Sumbermulyo village, Bambanglipuro sub-district, Bantul district which is about $20 \mathrm{~km}$ from the centre of Yogyakarta. This church has been very well known for its uniqueness in representing Javanese culture in every aspect of worship that is carried out. Almost all parts of this church are a form of inculturation of Catholicism into Javanese culture, including the liturgical music used in worship. Soenarja in (Usmanij, 2020: 23) says that inculturation is "an attempt to enter into a culture", permeating a culture and becoming a compound with a culture. There is an adjustment between one culture and the culture that will be included in this case is Catholic teaching which is included in Javanese culture in the Ganjuran area of Yogyakarta. Usmanij (2020:23) again said that inculturation is a process of adjustment, alignment, or the incarnation of the gospel into a particular culture. This is abundantly evident at the Catholic Church of the Sacred Heart of Jesus, Ganjuran, where the Bible is able to penetrate Javanese culture without destroying it. The term indigenization in the Catholic liturgy has the same meaning as inculturation. Hadi (2006:33) explains that the term indigenization which comes from the word indigenous, or Latin indigenous, means the term native or indigenous. This refers to a process that shows a form of liturgy of the original or indigenous culture of the local community and leads to a radical and comprehensive change. 
Volume 4 Issue 15 (December 2021) PP. 33-45 DOI 10.35631/IJHAM.415003

This indicates that essentially indigenization is the same as inculturation. One form of this inculturation lies in the music used in the services of the Ganjuran Sacred Heart Church. Gamelan music is used as a form of appreciation for Javanese culture as a place where the Church thrives. The process of incorporating Javanese culture into music (gamelan) is carried out without losing the Catholic liturgical principles. This is interesting because gamelan itself certainly has its own philosophy and meaning which is then combined with Catholic values, rules and teachings and can be packaged in the form of worship. A lot of gamelan gendhing is played to accompany worship in this church. Javanese music subtleties and religious components are woven together to create its unique "vibes". Gamelan is a means and a medium for people to strengthen their spirituality (in terms of worship). The sound of gamelan gendhing is able to create its own taste and atmosphere that is able to help the people who are the majority of the village community easily appreciate every worship song.This research will show how inculturated modern art (art items, artifacts, structures, and even Javanese music) may aid people's understanding of religious and aesthetic experiences in worship. These spiritual experiences that occur continuously and repeatedly are what then penetrates the minds of the people and is able to form a communal identity.

\section{Literature Review}

There are numerous studies that are related to the issue to be investigated, based on the search for past research. The relevant study is then turned into a literature review, which acts as a reference and reference material for determining the scope of the research's development. This is important for the study to be thorough by completing or filling the gaps in prior research. The first research was taken from the Journal of Recital volume 14 No.1 of 2013 written by Yohanes Don Bosko Bakok with the title Inculturative Liturgical Music at the Ganjuran Church, Yogyakarta. This study discusses liturgical music that has undergone a process of inculturation. The history of liturgical music is explained in the early sections of the text. This study focuses on the phenomenon of liturgical music that occurs at the Good Friday Mass at the Catholic Church of the Sacred Heart of Jesus, Ganjuran. The researcher wants to know the extent to which the provisions of universal liturgical music are used at the Good Friday Mass at the Church of the Sacred Heart of Jesus, Ganjuran. This is because the liturgical music at the Good Friday Mass at the Church of the Sacred Heart of Ganjuran undergoes an inculturation process, where there are adjustments of liturgical music with local arts and culture. The songs sung during the Good Friday Mass are as follows: Sungkawa (Condolences), Ayak Ayak Tlutur (sad), Gya Sumewa (all facing), Gusti Midhangetna (God Hear), Ngabekti Salib, Salib Suci (Holy Cross), Megatruh, Ing Ratri Njeng Gusti, Atur Roncen, Sri Jesus Di, Rama Kawula, Linuhurna Gusti, Puji Luhung and Sri Jesus Manis Ing Manah. These songs are accompanied by Javanese gamelan music and have become a tradition of this Church from generation to generation. The relevance of this research to this study is that both of them use the same place, namely the Church of the Sacred Heart of the Lord Jesus Ganjuran. In this study, the idea of inculturation is also employed, and it is one of the theories that contributes to the study's strength.

The second research is a journal article from the International Journal of Creative and Arts Studies Volume 6 No.1 written by Luca Pietrosanti in 2019 entitled The Gamelan in the Catholic Liturgy in Yogyakarta. This study also emphasizes the inculturation aspect that occurs in Catholic liturgical music in Yogyakarta. The material object observed is the conception of traditional gamelan music keys together with polyphonic choirs. The observations were made 
Volume 4 Issue 15 (December 2021) PP. 33-45 DOI 10.35631/IJHAM.415003

at the Yogyakarta Liturgical Music Center and the Ganjuran Church of the Sacred Heart of Jesus. This study describes the use of kidung accompanied by gamelan and its application to vocals / choirs. The correlation in my study is in the aspects of inculturation and the gamelan used to accompany the kidung.

\section{Research Methods}

This study uses a qualitative research method with a phenomenological approach. Qualitative research is research that seeks to analyse social life by describing the social world from the point of view or interpretation of individuals (informants) in a natural setting (Sudaryono, 2019:97). This is in line with Moleong (2014:3) which states that qualitative research is a research procedure that produces descriptive data in the form of written or spoken words from people and observable behaviour. According to Sudaryono (2019: 88) descriptive research is shown to describe a situation or phenomena as they are. What happens in the field. This shows that qualitative research refers to the description of an object that is studied in depth. The phenomenological approach is an idea of social reality, social facts and social phenomena that become a problem in research (Moleong, 2004:8).

Phenomenology also offers a descriptive, reflective, interpretive question model in order to obtain the essence of experience. Husserl and Hedegger in their descriptive phenomenology state that the basic structure of the world of life is focused on an experience (lived experience) which is considered as an individual's perception of his presence in the world (Anwar, 2010:42). The data generated in this study were taken with several data collection techniques, namely observation, interviews, documentation, and literature studies both offline and online. The "Taste" theory from Mark Benamou is also a theory that will analyse the data generated in the research. The object of this research is the Church of the Sacred Heart of Jesus, Ganjuran and its inculturation and activities.

\section{Results and Discussion}

\section{Art and Religion}

Religion is related to religiosity. Religiosity is personal where religion is able to provide inner experiences for humans to relate directly to God (transcendental). Humans play a role in reviving the concept of religion and art in themselves. This will be manifested in shaping the character and behaviour of humans themselves in people's lives. Humans are the main subject of the concept of art and religion that processes all elements of feelings, inner processing, enjoyment expressed through experiences. According to Marzali (2016: 68) says that humans cannot be simplified as mere bodies, or mere materials. In him there is something transcendental, which cannot be simplified. He is the self, that is, the main, inseparable aspect. Humans are the main agents of the processes that occur in life such as in artistic and religious experiences. Humans have something 'inside' that can interpret everything they catch into an experience that constructs themselves. Basically, art and religion have a close relationship. The relationship between art and religion can be said to make the two things commensurate. This may not be seen clearly because both are in different spaces. Art can still be found and appreciated in public spaces. Purwanto (2014: 154) says that the simple understanding of public space or what is often known as public space is a place that can be used by the wider community to meet their needs. Public space is a space provided by the government and can be freely accessed by the public. Currently religion cannot be equated with art in the context of the state because of the institutionalization process that occurs. Religion is no longer in the public sphere 
Volume 4 Issue 15 (December 2021) PP. 33-45 DOI 10.35631/IJHAM.415003

but has been privatized and sacred. Everything that touches the private sphere must strictly comply with applicable regulations. Not infrequently this causes friction and social conflicts that occur in society because privatization makes the essence of religion seem lost and turned into symbols that are glorified. This is what often triggers conflict with religious issues that occur in society.

The relationship between religion and art is also explained by several experts. Sumardjo (2000:22) explains that art experience is identical with religious experience. Art values are equivalent to religious values. Bahari (2017: 68) says that if art reaches its final goal, then it will participate together with religion and philosophy in interpreting and explaining the elements of divinity and most of the very deep and broad needs of humanity. Both statements illustrate that there is a relationship and even equivalence between art and religion where religious experience is equivalent to religious experience. Art and Religion can be found in a performance that is able to bring them together. This can be seen in how art performances are used as ritual suggestions (in worship). The sense of art and religion presented in the performance is received and felt by the senses through experience. Rosyid (2019: 86) said that what is understood from the link between religion and art in rites or performances is experiential and relates to experiences.

\section{Inculturation of the Sacred Heart of Jesus Catholic Church of Ganjuran}

The interconnection between art and religion can be found at the Catholic Church of the Sacred Heart of Jesus, Ganjuran, Yogyakarta. The process of inculturation of Catholic teachings into Javanese culture can be seen from every activity and artifact contained in the Sacred Heart of the Lord Jesus Catholic Church Ganjuran, Yogyakarta. This church has been very well known for its uniqueness in representing Javanese culture in every aspect of worship that is carried out. This is known as inculturation. In short, inculturation is the process of adapting another culture to the target culture in a particular community group. Hadi (in Soedarsono, 2010: 77) says that thus inculturation is a symbolic transformation process of the Catholic Church which is adapted to the socio-cultural conditions of the supporting community. Inculturation is also interpreted as a process of negotiation and cultural symbolic encounter in the space between (liminality space), which demands a creative process of adaptation and accommodation to the culture it enters (Tama, 2018:79). The adaptation of Catholic teachings to Javanese culture in the Ganjuran area took place in stages. The figures who initiated the inculturation of the Sacred Heart of Jesus Ganjuran Catholic Church were two brothers, namely Dr. Josef Schmuster and Ir. Julius Schmutser who is the owner of the Ganjuran-Gondanglipuro sugar factory. At first, they taught the social teachings of the Church to factory workers to gain their sympathy. An elementary school and health centre were also established which is now known as St. Elizabeth Hospital Ganjuran. In his book Soedarsono (2010:78) explains that it is clear, it cannot be denied that the role of the Pastor in the inculturation of the Church is very important, which in Javanese Catholic circles is considered as a messenger of God in the world, whom the people in Java get the call 'Rama'. 


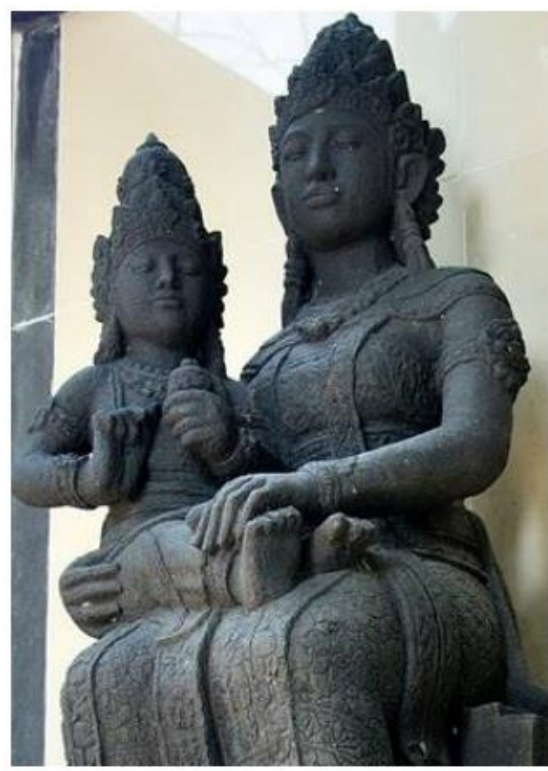

Figure 1: Mother Mary Statue Holding Jesus

Source: panduwisata.id

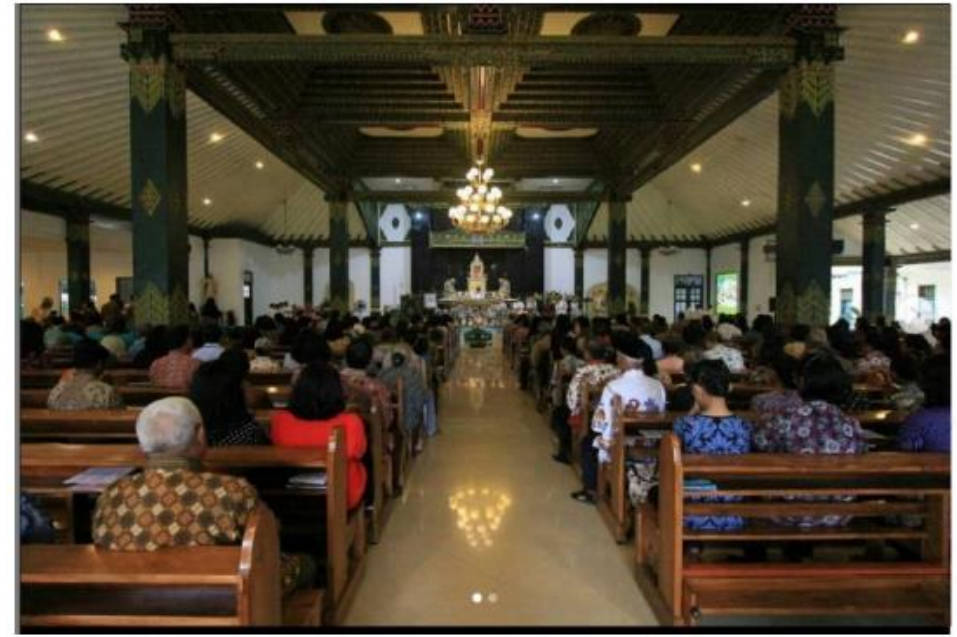

Figure 2: The Atmosphere Of Worship In The Main Church Building

Source. instagram.com/gerejaganjuran

Inculturation in the Catholic Church of the Sacred Heart of Jesus Ganjuran, Yogyakarta can be seen clearly from every artifact in the church environment. The main form of the church building is in the form of a joglo, where the joglo is a traditional Javanese traditional house. This Joglo building adopts a building like the Yogyakarta Palace. There is a pavilion in front which is also often used during Mass for Feast (Christmas or Easter) where when the main building is full, people can use the pavilion. There is a statue of Jesus made wearing traditional Javanese clothes. The statue of Maria holding the baby Jesus in the church is also made using traditional Javanese clothes like Dewi Sri. Temple buildings are also found in the church environment. This temple clearly represents Javanese tradition and has a Hindu style. This temple is surrounded by reliefs depicting the tribulation of Jesus. The temple is conical in shape like other Hindu temples. This temple faces south instead of east (like other Hindu temples) because it has its own philosophy.

There is a myth in Javanese culture where the south is always associated with the Ruler of the South Sea where Kanjeng Ratu Kidul reigns. Like the Javanese philosophy that this temple building does not turn its back to the South Sea. This temple is named the Temple of the Sacred Heart of the Lord Jesus in which there is a statue of the Sacred Heart of Jesus who wears the clothes of the greatness of the Javanese king who gets the title 'Sampeyan Dalem Maha Prabu Yesus Kristus Pangeraning Para Bangsa' (Soedarsono, 2010:80). On the day usually the temple courtyard is often used by people from outside Ganjuran to pray. The Mass held in the courtyard of the temple is the Mass on the first Friday night and the Procession (Anniversary of the Ganjuran Sacred Heart Church) and the World Food Day Commemoration, the rest are held in the church building. Masses that are held in front of the courtyard of the temple have Javanese nuances with waiters wearing Javanese clothes.

Inculturation can also be seen from the Eucharistic Liturgy which has been mixed with Javanese culture. Gamelan music is also used in worship. Gamelan music is usually combined 
Volume 4 Issue 15 (December 2021) PP. 33-45 DOI 10.35631/IJHAM.415003

with the waiters / officers of the Mass who wear traditional Javanese clothes with a Javanese (Krama Inggil). The Mass Procession is one of the biggest celebrations in the Sacred Heart of Jesus Catholic Church, Ganjuran, Yogyakarta. This procession is the anniversary of the Church of the Sacred Heart of Jesus Ganjuran which is held every 4th week in June. The procession begins with the female dancers who dance to open the way, followed by a procession from small children who are dressed like Javanese clown figures followed by officers who use traditional clothing with all the tools. Followed by a procession of mountains of various kinds of crops. This procession is carried out by walking from the sacristy, where the officers prepare themselves then circle the church and then head to the front accompanied by the sound of gamelan. This mountain of produce was then blessed by Father and distributed to the people to be eaten together as an expression of gratitude.

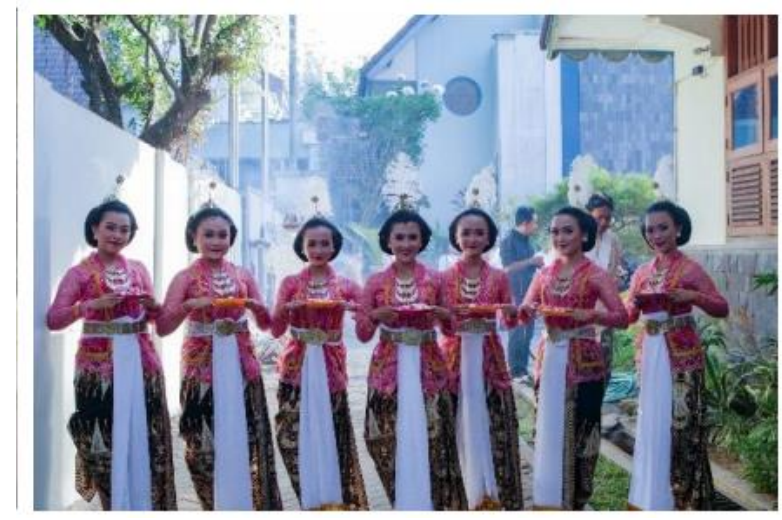

Figure 3: Nine Dancers of "Tari Putri"

Source: doc. Informant, 2020

The inculturation of music in the Catholic Church of the Sacred Heart of Jesus Ganjuran can be seen in the use of gamelan in worship and the Gejug Lesung art which has been scheduled to accompany praise in worship. Music is intertwined with religious and cultural expression and experience. In fact, music and singing allow people to participate emotionally and physically in their daily lives. Singing (music) is a way of life, an artistic expression of life's existential depth. (Utomo, 2019:3) .The Catholic Church of the Sacred Heart of Jesus Ganjuran has a book of songs (excluding Madah Bakti and Puji Syukur) which has been arranged by a devotee who is a native of Ganjuran who has musical talent. The devotee has died, and the songbook is held by Mr. Rama. This book contains a collection of Javanese hymns complete with notation and lyrics. This songbook is still used today with the accompaniment instrument that is always used is the gamelan. This songbook is the only one and is the hallmark of this church. 
Volume 4 Issue 15 (December 2021) PP. 33-45 DOI 10.35631/IJHAM.415003
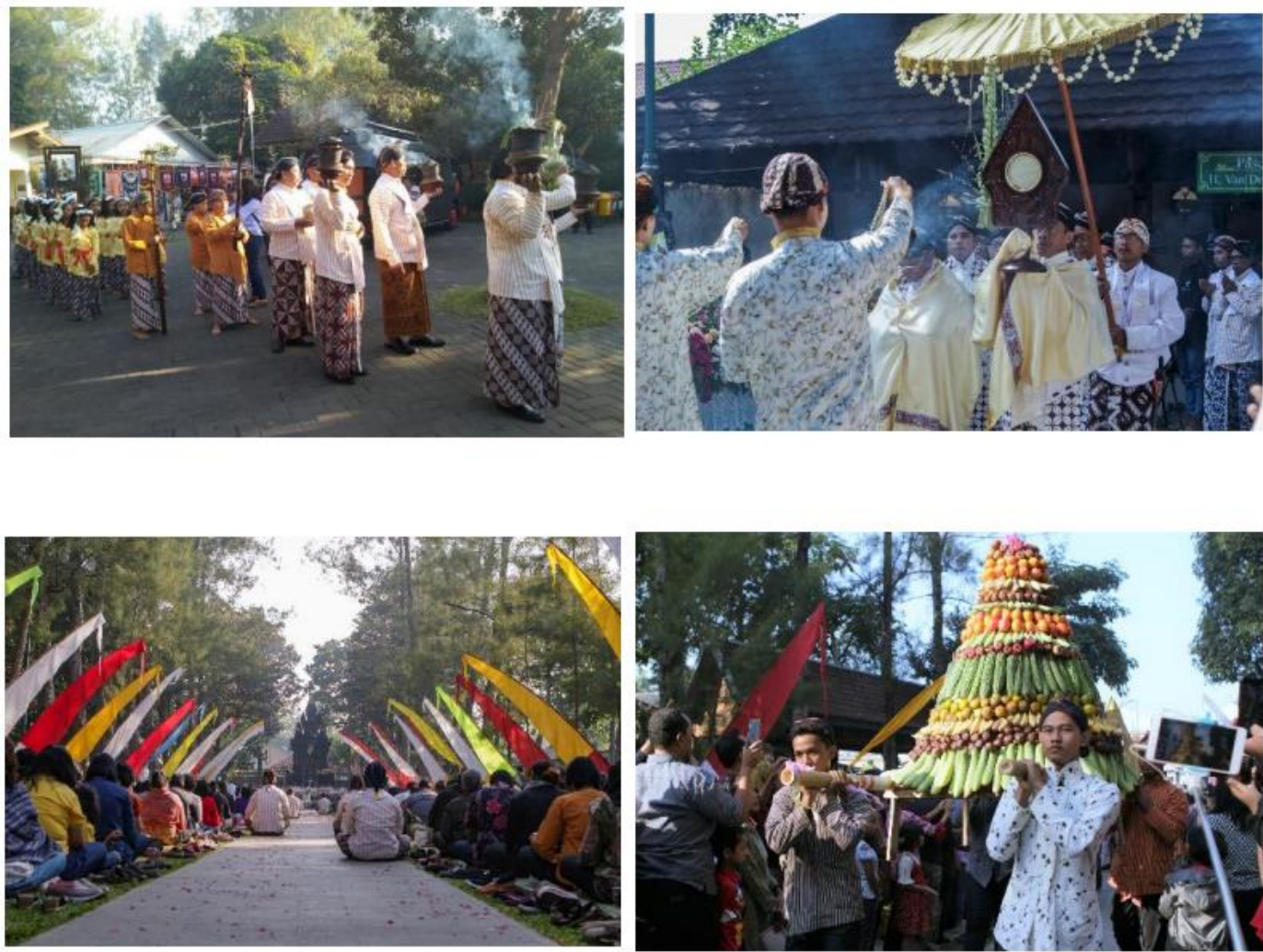

Figure 4: Anniversary Of Sacred Heart Of Jesus Catholic Chruch Ganjuran On June 2019

Source: Informant, 2020

\section{Spirituality in Contemporary Art}

Inculturation at the Sacred Heart of Jesus Catholic Church Ganjuran has also produced contemporary art which has become a means of worship. Contemporary art is a non-conceptual art form that inherits its concept from aesthetic modernism and absolute music, simply contemporary is a form that expand and have a radical transformation from its rule (Barret, 2021: 223). The music used in worship in this church is Javanese gamelan. For example, the First Friday Evening Mass of the Church of the Sacred Heart of Jesus Ganjuran is accompanied by Javanese gamelan played by a local gamelan group. Therefore, the songs used are in the form of gending. Liturgical music or also known as church gending is a composition of songs in Javanese karawitan in the form of vocals and instrumentals in slendro or pelog tunes specially presented for worship purposes for Christians (Driyastoto, 2018:6). Some of the gendhing used in worship are unusual because they come out of the Javanese gendhing standards. Javanese gendhing fused with Catholic principles to form a new aesthetic. Javanese gamelan generally uses sinden as a vocal. Suwardi (2006:5) argues that sinden is a woman who is in charge of voice (vocals) in the presentation of gamelan music. The gamelan music used in church services does not use sinden with titi laras pelog but uses a choral format with diatonic scales. This is interesting because the Javanese gamelan with titi laras pelog can be matched and collaborated with a choir with a diatonic scale. The Kendang in the gamelan and the Conductor in the choir play an active role in leading the presentation of the liturgical gamelan. Kendang together with the conductor work together in a musical communication to be able to lead and present a harmonious performance collaboration in a worship. Both play a very 
Volume 4 Issue 15 (December 2021) PP. 33-45 DOI 10.35631/IJHAM.415003

important role in achieving the success of the show. If there is an imbalance of beats/rhythms, it will be fatal to the continuity of the show. The creative process occurs when there is creation and merging of the two musical aspects with different aspects and produces/creates something new. The novelty produced is a new performance/aesthetic and forms a strong characteristic in the Catholic Church of the Sacred Heart of Jesus Ganjuran

The gamelan group at the Church of the Sacred Heart of Jesus Ganjuran is named Tyas Manunggal Maha Agung. This gamelan group consists of mostly young youth members of the local church. This church has succeeded in regenerating gamelan players under the guidance of Mr. Sariyata as a karawitan coach. Gamelan training is highly encouraged in this church because it is needed for worship purposes. The training process runs continuously, especially in preparing for worship every week. The routine worship that always uses gamelan is the First Friday Mass which is always held every month on the first Friday. Next is the Sunday morning Mass whose worship is always accompanied by gamelan beats. In addition to these Masses, worship usually uses organ musical instruments. While the choir that accompanies the gamelan, of course, also often holds exercises. The choir is named St. Cicilia. The choir consists of adult men and women belonging to the local church. St. Cicilia Choir does independent practice before going along with the gamelan to adjust the beats/rhythms that are built. The creative process can be seen in the collaboration of gamelan and choir practice, which of course requires a musical connection between the two in order to build the integration/similarity of "taste" and produce an interpretation according to the atmosphere of the song being sung. The songs that are performed are usually sourced from song books such as Kidung Adi, Madah Bakti, Puji Syukur and a collection of songs that were created by church elders such as (Alm). Mr. Saridal as the activator of the liturgical gamelan at the Catholic Church of the Sacred Heart of Jesus Ganjuran

Creativity is the ability to create (Damajanti, 2006:21). Meanwhile (Saefudin, 2012: 41) explains that creativity is a product of the ability (creative thinking) to produce a new way or something in dealing with a problem or situation. The implementation of the creative process is able to create gendhing that critically combines cultural and religious aspects in the context of worship music. This contemporary art is apparently able to bring. This is of course not without purpose and purpose, but to help people who incidentally live in rural areas where Javanese culture is still strong in order to live worship (the concept of inculturation). Contemporary art created through this inculturation turned out to be able to become a torch in the spirituality of the people.

The process of mixing the two things does not necessarily eliminate the meanings contained in the Javanese gamelan in the sense that the values of the Javanese gamelan can still be felt when the liturgical gamelan is played. Djohan (2009: 90) says that Javanese gamelan not only serves as a reminder to the public of its existence as Javanese but is also implicitly often referred to as 'tombo jampi stress' (stress medicine) or leisure entertainment. Javanese gamelan not only functions as klenengan but also klangenan (something that is liked and missed). Javanese gamelan art contains historical and philosophical values for the Indonesian people.

\section{Appreciation and Identity Formation}

The things that have been described above explain that gendhing is not only a matter of the fact that sound can be heard by the human senses but more than that, behind the fact that sound is stored other interesting dimensions that need to be expressed, including this "taste". The feeling 


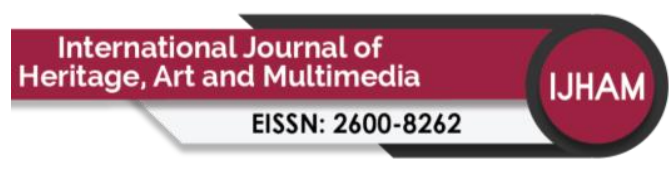

Volume 4 Issue 15 (December 2021) PP. 33-45 DOI 10.35631/IJHAM.415003

caused by the effect of the gendhing game actually does not come from the gamelan/gendhing, but in the heart of the person who listens (permeates) both a musician and a listener (in this case the people). This feeling is able to grow communally because of the social and cultural similarities. The church performs its role in the process of inculturation it does. Marc Benamou also said that Rasa, in the sense of "musical substance," is most commonly a mood or effect for Javanese artists. However, it might be something more abstract (such as a melodic essence) or something more tangible (such as the meaning of a gendhing's title). Because the content is mainly an emotion, expressing a rasa necessitates both comprehension and emotion, as does rasa itself. The type of knowledge I'm referring to is primarily an intuitive feeling of what the work is "about," but in certain situations this sense may be learned more intentionally, more self-consciously (for example, in a class or via discussion). Hadi (2006:14), explains that the Church and liturgical ceremonies in Ganjuran are located in a traditional rural community environment, so the various forms of symbols are mostly associated with environmental knowledge. The Church tries to show its views and participation in all aspects of human life, including culture and its development. As it is known that traditional rural communities prioritize the knowledge system of perceptions about the environment or daily knowledge, rather than various other knowledge. The liturgical gamelan in the Church of the Sacred Heart of Ganjuran has a special characteristic compared to other places. This is of course influenced by its geographical location, where the Ganjuran community is more agrarian and in a rural setting so that the nuances of the gamelan are subtle according to Javanese standards. This is not seen in the Kotabaru Church and the Pugeran Church which, although still in the Yogyakarta area, have different characteristics.

Gamelan at the Sacred Heart of Jesus Catholic Church Ganjuran can be said to be classical gamelan / which is pure Javanese gamelan. This can be seen from every worship that takes place, gamelan is one of the sacred devices where the players must really understand and understand the meaning and feeling of playing the gamelan. The training that is carried out is aimed at making the musicians able to play the gamelan in the right way because this is related to the "taste" or interpretation that is built. This makes gamelan players at the Church of the Sacred Heart of Jesus Ganjuran really have to understand the ins and outs and the meaning of liturgical gamelan and Catholic teachings correctly so that when playing the gamelan they are able to produce a communal "taste" that is accepted by the people in worship. Gamelan in this church never provides variations or insertions such as Balinese gamelan or festive elements because it is standard. It is different from the gamelan in Kotabaru Church in Yogyakarta, which is dominated by young people, for example, has a more modern gamelan feel/style. This church often inserts gamelan from other regions such as Balinese, Sundanese, etc. gamelan. Gamelan in this church also often adds elements that make gamelan seem lively. While the gamelan at the Pugeran Church can be said to be semi-standard because it is almost the same as Ganjuran, but in this church there are still sounds of gamelan compositions with festive elements.

These are the things that affect the appreciation of the people when worshiping which also depends on their socio-cultural conditions. Gamelan in this church does have its own characteristics compared to gamelan in other churches, although it is still within the scope of Yogyakarta. This is because the socio-cultural context greatly influences it, for example the Ganjuran people who live in the countryside (agrarian) will be different from the people in Kotabaru who live in the city and most immigrants / young people or in historical they are dominantly used by Dutch. These collective experiences of "roso" then shape the identity of 
Volume 4 Issue 15 (December 2021) PP. 33-45 DOI 10.35631/IJHAM.415003

the members of the Church of the Sacred Heart of Jesus Ganjuran (Benamou, 2010:189). The formation of the identity of the members of the Sacred Heart of Jesus Church through Gamelan music has been going on continuously since this Gamelan became an accompaniment in worship.

The existence of a deliberate element in the formation of this identity has the intention of helping rural Catholics to facilitate their appreciation when worshiping (with an inculturative liturgy that has been adapted to local culture). This process takes place continuously and has penetrated the hearts of the people collectively (forming a habitus) which in the end also gives rise to a characteristic/identity. The process of inculturation that occurs also departs from the local culture so that the local community is very accepting of its presence. The formation of a new identity is also one of the functions of music. Barker (2005: 218) explains that the characteristics of music, which are very easy to influence the feelings and emotions of the performers and listeners, cause each type of music to have its own characteristics and form the identity of the performers, listeners and the wider community. Identity is a sign that distinguishes a person from others. Identity is an essence that can be signified with signs of tastes, beliefs, attitudes, and lifestyles. This process of identity formation is a form of Contemporary Art where the socio-cultural situation through the process of inculturation becomes the trigger.

\section{Conclusion}

The correlation between art, religion and culture can be clearly seen in the Church of the Sacred Heart of Jesus, Ganjuran, which is almost all Javanese in style. The process of inculturation, namely the adjustment of Catholic teachings to the local culture (Ganjuran) went very well without causing social friction. This inculturation process can be seen from all aspects contained in the church including artifacts, processions, buildings and one of them can be seen from the liturgical gamelan music used in worship. Contemporary art which is a product of inculturation lies in all kinds of worship activities that always intersect with art, including worship (mass), processions at the Anniversary of the Church of the Sacred Heart of Jesus Ganjuran, and the liturgical gamelan music used. The liturgical gamelan used is a beautiful combination of Javanese gamelan with titi laras pelog with a choir with a diatonic scale of SATB format. These new things that appear are the result of a creative process which still does not leave the values and meanings of its origin (Javanese gamelan).

The purpose of the inclusion of this gendhing into the liturgy of the Church is none other than to help the people's appreciation in worship. This is done based on the socio-cultural aspects of the people who generally work as farmers living in rural areas who still hold strongly to their cultural culture. Gamelan is not only a matter of sound facts but also interesting dimensions/metaphors that deserve to be expressed, including "feel". These feelings and appreciations can grow communally because of the social and cultural similarities. The formation of the identity of the Church of the Sacred Heart of Jesus through Gamelan music has been going on continuously since this Gamelan became an accompaniment in worship. The existence of a deliberate element in the formation of this identity has the intention of helping rural Catholics to facilitate their appreciation when worshiping (with an inculturative liturgy that has been adapted to local culture). This process takes place continuously and has penetrated the hearts of the people collectively (forming a habitus) which in the end also gives rise to a characteristic/identity. The things above become a real explanation that contemporary art 
Volume 4 Issue 15 (December 2021) PP. 33-45 DOI 10.35631/IJHAM.415003

because of inculturation is able to become a means of spirituality for the people (in this case the Sacred Heart of Jesus Ganjuran Catholic Church).

\section{References}

Anwar, D.G., (2010). Pengantar Fenomenologi. Depok: Koekoesan.

Bahari, N. (2017). Kritik Seni. Yogyakarta: Pustaka Pelajar.

Bakok, Y.D.B., (2013). Musik Liturgi Inkulturatif di Gereja Ganjuran Yogyakarta. Journal of Resital, 14(1), 24-32.

Barret, G. (2021). Contemporary Art and the Problem of Music: Towards a Musical Contemporary Art. Twentieth-Century Music, 18(2), 223-248.

Barker, C. (2008). Cultural Studies Teori \& Praktek. Yogyakarta: Kreasi Wacana.

Benamou, M. (2010). Rasa (Affect and Intuition in Javanese Musical Aesthetics), Oxfort: Oxfort University Press.

Damajanti, I. (2006). Psikologi Seni. Bandung: PT Kiblat Buku Utama.

Djohan. (2009). Respons Emosi Musikal. Yogyakarta: Joglo Alit.

Driyastoto, R. (2018). Gending Dalam Misa Malam Jumat Pertama Di Gereja Hati Kudus Tuhan Yesus Ganjuran Sebagai Salah Satu Wujud Inkulturasi Budaya. Yogyakarta: Institut Seni Indonesia

Hadi, Y. S., (2000). Seni dalam Ritual Agama. Yogyakarta: Yayasan untuk Indonesia.

Hamilton, E. (2018). From Organ to Gamelan: Javanese Catholic Musical Traditions In Yogyakarta, Central Java. Independent Study Project (ISP) Collection. 2939.

Marzali, A. (2016). Agama dan Kebudayaan. UMBARA: Indonesian Journal of Anthropology, $1(1), 57-75$.

Moleong, J.L., (2014). Metode Penelitian Kualitatif , (Rev. Ed). PT Remaja Rosdakarya: Bandung.

Prietosanti, L. (2019). The Gamelan in the Catholic Liturgy in Yogyakarta. International Journal of Creative and Arts Studies, 6(1), 23-31.

Purwanto, E. (2014). Privatisasi Ruang Publikdari Civic Centre menjadi Central Business District (Belajar dari Kasus Kawasan Simpang Lima Semarang). Journal of Tata Loka, 16(3), 153-167.

Rosyid, N. (2019). Mengenalkan Antropologi Inderawi Dalam Memahami Pertautan Instrinsik Agama Dan Seni: Pandangan Awal. Patrawidya Journal, 20(1), 83-100.

Saefudin, A.A. (2012). "Pengembangan Kemampuan Berpikir Kreatif Siswa Dalam Pembelajaran Matematika dengan Pendekatan Pendidikan Matematika Realistik Indonesia (PMRI)". Al-Bidayah Journal, 4(1), 37-48.

Soedarsono. (2010). Seni Pertunjukan Indonesia di Era Globalisasi. Yogyakarta: Gadjah Mada University Press.

Sudaryono. (2018). Metodologi Penelitian (Kuantitatif, Kualitatif, dan Mix Method), (2nd ed). Kota Depok: PT Raja grafindo persada.

Sumardjo, J. (2000). Filsafat Seni. Bandung: Institut Teknik Bandung.

Suwardi. (2006). Seni Karawitan 2. Yogyakarta: FBS Universitas Negeri Yogyakarta.

Tama, S. A.H.P. (2018). Inkulturasi Prier Memperkaya Ekspresi Iman Dengan Musik. Journal of Theology, 7(1), 77-96.

Usmanij, P. \& Ganesha, M A. (2020). “Tinjauan Teologis Mengenai Pemahaman Umat terhadap Inkulturasi dan Dampaknya: Studi Kasus Gereja Katolik Ganjuran”. Gamaliel Journal, 2 (1), 20-37. 
Volume 4 Issue 15 (December 2021) PP. 33-45 DOI 10.35631/IJHAM.415003

Utomo Y.K., et al. (2019). "Liturgical Inculturation at Javanese Christian Church, Gondokusuman, Yogyakarta”. Proceedings of the 5th International Conference on Science, Education and Technology, ISET 2019, 29th June 2019, Semarang, 1-6. 